\title{
Demand patterns of rice imports in Malaysia: implications for food security
}

\begin{abstract}
Malaysia is a net importer of rice. More than a quarter of its rice requirement is met by import. Rice imports play a crucial role in determining the country's food security. Import strategy of the company, which owns the exclusive import right, has a profound impact on an array of economic, political, and societal stabilities. However, domestic agricultural policies and relevant past studies have not addressed the strategic concern in the current food security framework. Therefore, this study analyzes demand patterns of rice imports in Malaysia with an ultimate intention to provide policy implications for its food security. From the Error Correction Model of Almost Ideal Demand System (ECM-AIDS), estimates of demand elasticity suggest that rice imports will be narrowly sourced, largely from Viet Nam with Thailand second in importance. Such an import strategy is similar to the pre-crisis model, which was weak in mitigating negative effects of supply disruption during the Food Price Crisis 2007/08. Instead, the exclusive importer could (1) multi-source rice imports, (2) import paddy (for longer storage life and supporting downstream activities), and/or (3) balance its business orientation with the national food security. In sum, this study provides evidences for the need to consider rice imports in the country's future food security framework.
\end{abstract}

Keyword: Rice imports; Demand patterns; Food security; Malaysia 